\title{
THE RELATIONSHIP BETWEEN ENTREPRENEURIAL LEARNING AND BUSINESS PERFORMANCE: THEORETICAL AND EMPIRICAL EVIDENCE
}

\author{
DOI: 10.17261/Pressacademia.2018.814 \\ RJBM- V.5-ISS.1-2018(3)-p.22-33 \\ Hewa Kumbalgoda Gamage Sriyani Ranasinghe ${ }^{1}$, Mohd Shukri Abd. Yajid ${ }^{2}$, Ali Khatibi ${ }^{3}$ \\ ${ }^{1}$ University of Sri Jayewardenepura, Nugegoda, Sri Lanka. \\ hksri@sjp.ac.lk, ORCID: 0000-0002-7205-4783 \\ ${ }^{2}$ Tan Sri. Dato' Wira Dr. Mohd Shukri Abd Yajid, Management \& Science University, Shah Alam, Malaysia. \\ mohd_amin@msu.edu.my \\ ${ }^{3}$ Ali Khatibi, Management \& Science University, Shah Alam, Malaysia. \\ alik@msu.edu.my
}

To cite this document

Ranasinghe, H. K. G. S., Yajid, M.S.A., and khatibi, A. (2018). The relationship between entrepreneurial learning and business performance: theoretical and empirical evidence. Research Journal of Business and Management (RJBM), V.5(1), p.22-33

Permemant link to this document: http://doi.org/10.17261/Pressacademia.2018.814

Copyright: Published by PressAcademia and limited licenced re-use rights only.

\begin{abstract}
Purpose- The objective of this article is to examine the components of entrepreneurial leaning based on competency approach, motivation and traits theories to propose a conceptual framework with knowledge, skills, attitudes, motivation and traits. A severe shortage of studies relevant to Sri Lanka is observed in comparison with the western countries where specific dimensions linked with entrepreneurial leaning have been revealed.

Methodology- These specific dimensions are selected instead of others based on the more practical application for the graduate entrepreneurs in the education sector in Sri Lanka and it is a new trend in the academic perspective.

Finding- It is significant that research conducted up to now, education activates of graduate entrepreneurs in the university system is lack a general frame, where queries on the subject of EL still remain unreciprocated.

Conclusion- The proposed recommendations strongly advocate for future empirical research of this valuable topic, thus adding new knowledge to the existing.
\end{abstract}

Keywords: Entrepreneurship, entrepreneurial learning, competencies, motivation, draduate entrepreneur JEL Codes: L26, L31, P13

\section{INTRODUCTION}

Academics and creators of new ventures in the field of entrepreneurship which is applicable throughout the world (Sok, Snell, Lee, \& Sok, 2017) and consider entrepreneurial learning (EL) as a vital area for investigation, which needs more attention and expansion (Wang \& Chugh, 2014). Further, in the Sri Lankan context, it is significant that there is an enormous gap when compared with the western countries (Kumara, 2012). In the present context EL is identified as a mirror image of the local competitive advantages and disadvantages of the exterior environment or, by and large microeconomic business, social and economic conditions (Nicolae, Ion, \& Nicolae, 2016). In addition, EL can be defined as a process of lifelong learning in multiple disciplines improving competence across individual development, proficiency in society, generating employment and starting entrepreneurial businesses that promote social and cultural environment (Bacigalupo, Kampylis, Punie, Van den, \& Brande, 2016).

Therefore, it is vital of this discussion in a contemporary society giving special attention in the sustainable development of a country. 
EL is vital for the sustainability of any country (Lomberg, Urbig, Stöckmann, Marino \& Dickson, 2017; Sok, Snell, Lee, \& Sok, 2017). Many authors have considered different perspectives of theories to emphasize the relationship between EL and its numerous dimensions (Ernest, Matthew \& Samuel, 2015). However, it is evident that in the Sri Lankan context few studies on EL had been carried out previously to examine this vital relationship using several components under specific theoretical backgrounds (Kasturiratne, 2012; Ranasinghe, 2008). One such study conducted on international enterprise education in Sri Lanka; a blended approach, highlighted that some important dimensions considered were entrepreneurial aptitude, intension and self efficacy. Further it is also clear that many research which elaborated on the above factors, were focused on different theories and models. However most of these studies were based on enterprise education but not university education. When considering university education in Sri Lanka, one case study conducted by Plymouth University in collaboration with University of Colombo and University of Kelaniya in Sri Lanka concluded in successful enterprise challenges in central Colombo focusing on the Sri Lanka tourism industry. This case study was based on blended, incremental delivery approach adopted and analyzing the multiple data sources. Majority of these studies were conducted in Sri Lanka, by using limited dimensions of EL when compared with the western context. Although there are many relationships and conceptualizations with regard to EL adopted in the west, these have not been applied in the Sri Lankan context due to limited perception, reluctance to try new concepts for the fear of unsuitability as a result of cultural, social and environmental factors. It is necessary to overcome this situation for the sustainable development of the country and this present study aims to contribute towards this exercise. Hence it would be appropriate to adopt the theories, concepts, models and frameworks tried out in the west, such as entrepreneurial motivation, personality development and competencies of the persons in relation to the university system.

Therefore this article has two aims and the first is to examine the dimensions in relation to EL in the university system. In order to fulfill this requirement, at the outset, theoretical concepts of EL were studied with a view to identify the different types of dimensions on the basis of the suitable theories, approaches, and models. The second aim is to develop a conceptual framework depicting the relationship EL has, with the dimensions exclusively selected for this article, in relation to the exhaustive literature review on the subject. Therefore, the ultimate intention of this article is to examine the dimensions in relation to EL and the proposed conceptual framework, consisting of dimensions in relation to different disciplines would be explored in future studies specially focusing on graduate entrepreneurs in the universities around the world.

Furthermore, researchers are allowed to discover the associations among various academic approaches, learning outcomes and subsequent career entrepreneurial performance by exploring EL which is an area that needs continuing accurate research (Buckley, 2014; Fani, 2015). It is also worthwhile to note that EL could be validated and tested through the graduate entrepreneurs in the university systems (Dermol, 2010) including Sri Lanka. It would be possible to evaluate graduate entrepreneurs in the EL environment of the University of Sri Jayewardenepura (USJ) which is a state university in Sri Lanka, that was considered as the study area for this article. In order to establish a strong basis on the vitality of EL a sound theoritical review of the literature is essential.

\section{LITERATURE REVIEW}

\subsection{Theoretical Development}

Theories need not be regarded to be purely academic since these help to understand basic concepts that are required to take decisions and activities with a clear mind in an improved manner rather than without any explanation or theory. At all possible levels, theories can basically have an impact on in influencing conclusion and activities. The disputes that arise in consequent to disparities in descriptions could be due to the theories that require testing (Migiro, 2014). This section provides a brief explanation for the literature related to EL giving priority to dimensions which were selected to be relevant to graduate entrepreneurs in the Sri Lankan state Universities. The narrative style is used to prepare this article exploring the vast knowledge on the current topic instead of the systematic literature review.

\subsection{Review of Entrepreneurial Learning (EL)}

EL is a part of lifelong learning (Sazen-Gultekin \& Gur-erdogan, 2016) and it is a phenomenon that can be observed, a process entrepreneurs engaged in and regarded as important since it is a concept which has been given high assessment in academic literature in the past decade (Ernest, et al., 2015, Sazen-Gultekin \& Gur-Erdogan, 2016; Toktarova, 2015). From 1970s a large number of methodical research have been conducted in relation to EL in the universities (Biggs \& Tang, 2011; Entwistle \& Ramsden, 1983; Laurillard, 2002; Marton \& Saljo, 1976a, 1976b; Prosser \& Trigwell, 1999; Ramsden, 2003). These research findings have led to identifying the main components related to EL environment (Entwistle \& Smith, 2002) which indicates that EL can be applied to areas such as social, community, family, education and government sectors which are of interest in the society (Buckley, 2014). 
EL appear to be a idea at the boundary of entrepreneurship and institutional development learning (Wang \& Chugh, 2013) and it is a consequence of practice on entrepreneurial behavior (Houwer, Gawronski \& Barnes-Holmes, 2013) which led to theory of planned behavior (TPB) model in the literature. This article uses TPB model to identify the behavior representing different dimensions in relation to the graduates' EL environment along with their entrepreneurship intention. Moreover, TBP in the case of new comers who start new ventures, should process best proactiveness by intentions towards the behaviour. EL attracted the interest of many researchers during 1990s as graduates experienced in learning, reached the upper echelon in higher education due to increased graduate intakes and differentiation (Poon, 2013). Researchers generally gather information on EL by studying what, how and why entrepreneurs learn (Cope, 2011). An important issue that needs to be highlighted in relation to EL is that a business can succeed or fail (Fani, 2015) depending on the learning environment of the individual and the process of EL is not similar among two persons (Schmeck, 1988). One learner's method of learning could be the preservation of information through learning by heart and retrieval, while trying to know the meanings and understand the reality could be another learner's technique (Ruhnau, 2006). Normally, all learners have differences concerning their usual capability with their preference in handling information and ability to transmit that knowledge in a suitable way (Jonassen \& Grabowski, 1993).

EL has been measured using different, theories, perspectives and models in the literature during a considerable time span. It is important to reflect on some of the processes which are of interest to this article are stated for the sake of completeness of this central topic. The competency approach which is expressed in terms of EL mainly selects the considerable part of the selection of dimensions. It is interpreted as a competency which helps to measure entrepreneurial attitudes, entrepreneurial skills and entrepreneurial knowledge (Sanchez, 2011) which are the first three components considered in the present article. An empirical study revealed the prime importance of the above competency factors of entrepreneurs in handling entrepreneurial activities and issues connected with EL processes (Ernest et al., 2015). Another relevant point of view considered in this article is the need theory (Murray, 1938) which is based on the requirement to understand the association between the social backgrounds and individuals' comfort level (Deci \& Ryan, 2002) where motivation can be used to evaluate EL. Another popular EL monitoring process is the big five personality model which is based on five personality components namely openness, conscientiousness, extraversion, agreeableness and experiences which suggest the importance of traits for EL. Competency approach allows studying the behavioral styles for successful learning at a proficient standard in various perspectives and the effect of diverse issues in relation to learning. TBP is the foundation for the competency approach and EL activity undoubtedly symbolizes this model (Krueger \& Carsrud, 1993). A study mentions that the field of entrepreneurship has mainly neglected TPB in their research although many other disciplines have widely used this theory in practicing their research (Krueger \& Carsrud, 1993). Hence, based on the competency approach, need theory of motivation and the big five personality model of traits explained above and considering the EL environment of the graduate entrepreneurs, this article develops the proposed conceptual framework.

\subsection{Gap analysis: research gaps and issues in entrepreneurial learning}

Thorough study of relevant literature highlighted numerous studies conducted in the field of EL as well as the areas which needs more research. During this exercise five gaps in relation to Sri Lankan context, were exposed on the examination of the selected literature.

Gap One - EL has been integrated with other related studies in different industries, and in various perspectives providing a contribution to future research in the western countries. However, this trend is yet to be achieved in the Sri Lankan context which results in a knowledge gap. Among the vast number of studies in the western part of the globe, a study relevant to EL that was carried out in Turkey using a sample of 328 is "The Relationship and Effect between Lifelong Learning Tendencies and Social Entrepreneurship Characteristics of Prospective Teachers" (Sezen-Gultekin \& Gur-Erdogan, 2016). The key findings of the study highlighted that EL tendencies such as knowledge, skills and attitudes have a positive relationship with entrepreneurship. The study titled "Does an action-based entrepreneurship education mean action heroes? Impact assessing an action-based entrepreneurial venture creation program" was conducted by an empirical research in Norway with a sample of 94 . According to this student goal oriented entrepreneurial self-efficacy (ESE) is clearly influenced by carrying out venture creation program process. However, the impact of entrepreneurial knowledge on EL has been highlighted as vital research area in literature (Ernest, et al., 2015).

Gap Two - In the western countries, many empirical findings and comprehensive research emphasizes a variety of learning prospects that improve entrepreneurial skills (Fayolle \& Gailly, 2008; Heinonen \& Poikkijoki, 2006; Okudan \& Rzasa, 2006; Zhao, Seibert \& Hills, 2005). In the Sri Lankan context, a gap of practical and theoretical studies on entrepreneurial skills in relation to EL is observed (Kumara, 2012). The relationship between entrepreneurial skills and EL plays a vital role in a person's life in the economical perspective (Sahban, 2014) and the impact of entrepreneurial skills on EL is worth mentioning (Ernest et al., 2015). The major variables that affect the competitiveness of business to a certain extent are entrepreneurs' management, the technical knowhow in the relevant field and the skills along with their psychological and behavioral characteristics. Literature emphasizes that there is a difference in students' direction of learning by any method 
and their capability of using the learning tactics. A study titled "Pedagogical Management of Learning Activities of Students in the Electronic Educational Environment of the University: A Differentiated Approach" was designed in Russia using 87 students as sample (Toktarova, 2015). This research proved that the necessity of developing the learning skills at a elevated standard, quality direction and proper instructive arrangements are responsible for academic management in such higher education institutes.

Gap Three - In the Sri Lankan context very few research is carried out in the field of entrepreneurial attitudes in relation to EL and it has to be highlighted as the gap that needs to be elaborated (Kumara, 2012). The association among entrepreneurial attitudes and EL is identified cleary (Ernest et al., 2015). Some of the research have expressed that entrepreneurial attitude is a major dimension of EL (Moen \& Allgood, 2009). Further, a positive relationship between possessing a favorable attitude during the period of the specific time and superior learning achievements is specified in literature (Perkins, 2004). An empirical study conducted in Trinidad using 60 youths titled "Making a Living in Trinidad: An Ethnographic Exploration of Entrepreneurial Learning among Youth" concluded that youth practice and learn entrepreneurship in families and educational establishments, where diverse, but positive attitudes, balanced knowledge and creative skills are offered.

Gap Four - The majority of the empirical research is done on the role of entrepreneurial motivation in the western countries (Aldrich \& Zimmer, 1986). It is conspicuous that in spite of the magnitude of value given to entrepreneurial motivation in EL, the number of empirical studies done in Sri Lanka are minimal (Kumar, 2012). This topic represents the importance of entrepreneurial motivation in running an enterprise which resembles the function of fuel or power for a vehicle. The literature has emphasized that in the entrepreneurial process, a vital role is played by entrepreneurial motivation (Baum \& Locke, 2004). A study was done in USA using 229 entrepreneurs, Chief executive officers and 106 assistants in the same field. This research investigated the association of entrepreneurial traits, skills and motivation to successive venture growth" (Baum and Locke, 2004). The results indicated that motivation was related to goals of the venture run by the entrepreneurs.

Gap Five - The opportunities for research investigation based on the study of entrepreneurial traits by giving importance to personal characteristics are noteworthy, and it leads to prospects for psychology researchers within the entrepreneurship setting in the western context (Baum \& Locke, 2004). On the other hand very few studies is done in Sri Lanka, to investigate the connection of entrepreneurial traits and EL (Ranasinghe, 2008). It has been identified that the characteristics of an entrepreneur which are considered in personality traits studies to examine the factors have an effect on the business success. Some studies reveal the progress of small business depends on the traits of the business holder (Ahmad, Ramayah, Wilson \& Kummerow, 2010; Blackman, 2003; Kiggundu, 2002; Kotey \& Meredith, 1997; Lee \& Tsang, 2001; Man, Lau \& Chan, 2002; Man \& Wafa, 2008; Nimalathasan, 2008; O’Regan, Sims \& Ghobadian, 2005; Zoysa \& Herath, 2007) who is responsible for success of a business and a new trend has emerged lately, to study the significance of traits for venture success (Baum \& Locke, 2004; Sarwoko, Surachman, Armanu, Hadiwidjojo, 2013). A study entitled "Entrepreneurship Traits and Social Learning Process: An Overview and Research Agenda" (Royo, Sari \& Shaari, 2015) was implemented concerning automotive industry in Malaysia. The conclusion conveyed that since EL is relied on the body of knowledge which is acknowledged as exclusive, hard to imitate and uncertain which will lead to entrepreneurial action. Therefore human dynamics help to understand how traits could influence building up of entrepreneur's current and future individuality.

Apart from the lack of quality theoretical application of EL in the literature, there is significant desire in this specific field for the academic research and in fact EL has benefited to have a high demand in the university system (Royo et al., 2014). The literature has proved that EL is able to build the quality and quantity of graduate entrepreneurs who contribute to the sustainability, focusing the wealth of economy of the country (Royo et al., 2014). However, in the Sri Lankan context very few studies have been conducted in these fields and the importance of EL has to be highlighted which are the gaps that need to be elaborated. Hence, the broad gap of theoretical and empirical studies of EL in relation to entrepreneurial knowledge, attitudes, skills, motivation and traits in one single study is apparent in the Sri Lankan context. Therefore, it is proposed that the results of this article may support to fill these gaps to some extent.

\subsection{The organization of the concept of entrepreneurial learning}

Although, EL is recognized for all its value and potential, it is unique since it engages in stimulation of knowledge, expression, involvement and purpose (Royo et al., 2014). Moreover, the importance of EL standard at university level has been highlighted in detail (Entwistle \& Smith, 2002). Published researches also emphasize the different dimensions of EL for progressive conduct (Baldwin-Evans, 2006; Harris, Sapienza \& Bowie, 2009; Mitchell \& Honore, 2007; Poon, 2013). Taking into account the Sri Lankan environment of graduate entrepreneurs, the article develops a conceptual framework on EL, based on the competency approach and some theoretical views corresponding to attitudes, skills, knowledge (Earnest et al., 2015) motivation (Gibb, 1994) and traits (Sanchez, 2011) which become useful to perform specific functions of the business. At this point it should be stressed that although selected dimensions of EL have been studied by the author to a great extent, majority of studies in the literature appeared to be fragmented and did not reflect its connection to $\mathrm{EL}$ 
directly. Hence, an attempt is made to formulate a conceptual framework to study the association among EL and the selected five dimensions which are explained below in details.

Knowledge of Entrepreneurship - An aspect that has been considered as creating a noteworthy impact on entrepreneurial success is the knowledge of entrepreneurship (Ahmed et al., 2013). Entrepreneurial knowledge is a major factor that can be enhanced in the form of human-capital asset. Knowledge is of prime importance with regard to technical, financial, organizational, and legal abilities etc. (Kuratko, 2005). The underlying principle of entrepreneurial knowledge is known to be taking the maximum benefit of the efficiency related to knowledge in the business venture and sustain the results (Wiig, 1997). It can be stated that management of knowledge is management of people and vice versa is also true (Davenport \& Volpel, 2001 as in Fani, 2015). Knowledge is comparable with water because when knowledge is not shared and updated it can get deteriorated similar to stagnating water that gets spoilt and lose all its good quality (Liao, 2002 as cited in Fani, 2015). Gaining knowledge is considered as the major requirement for the improvement of any system (Earnest et al., 2015) including university environment. Undoubtedly, EL is the way to obtain knowledge on a new field or to enhance the existing capacity of comprehension (Rae, 2004).

Entrepreneurial Skills - Entrepreneurial skill can be defined as a combination of creativity, analysing, motivating, networking adaptability and financial management competence (Ernest, Matthew \& Samuel, 2015). Skill can be considered as an important requirement to fine tune the graduates of various higher education institutions to face vigorous social and economic situations by providing information and talents in relation to the activities of businesses in addition to running individual businesses (Plaziak \& Rachwal, 2014). Investigation on this concept is carried out for more than ten years and it has been discovered that the talents, awareness in relation to the skills for various steps of venture process is attained through effective EL enabling these to be utilized later (Dehghani et al., 2014). Competence is considered as a blend of knowledge, skills and attitude to be possessed by employees for performing their jobs and competence-based education has been given more prominence during the past decade while it is presently becoming popular in a number of countries (Stoof, 2005). It is highlighted that the key entrepreneurial competencies that are perceived by students can be in the order of attitude, knowledge and skill while skill factor has an enormous influence on entrepreneurs handling activities and issues in relation to EL processes (Earnest et al., 2015). It is observed that the term competence is a wide concept although the definitions have comparative variations and it is constantly linked with skills, which is an element that needed to be used by competent entrepreneurs to handle the activities and issues in relation to their actions of EL (Earnest et al., 2015). Hence skills enable the entrepreneurs to cope up with challenges and doubtful situations which are typical for venture start-up and self employment.

Entrepreneurial Attitude - Attitude can be defined as a feeling toward an object, i.e. an affective component (Koballa, 1988). Entrepreneurial attitude is a vital dimension which can be referred to as the individual consciousness a person would have for creating his or her own business perception during the development of a business (Thompson, 2009). It is noteworthy to recognize that EL, the graduate received in their universities, invariably has an impact on their entrepreneurial attitudes and provides them the required know how along with skill needed for the entrepreneurial process (Matlay, 2006 as cited in Royo, Sarip \& Shaari, 2014 ). Positive attitude leading to change and several other factors were identified as needs for EL and it is believed that entrepreneurial educators and practitioners are in a position to have an impact on entrepreneurial attitudes (Lambing \& Kuehl, 2007). Further it is noted that EL shows an affirmative connection with attitude while the concept of entrepreneurial attitude is being used to measure the impact of EL on student's perceptions and motivation in relation to entrepreneurship as a feasible carrier opportunity. The decisive manner of self efficacy on students' motivation, learning, and accomplishment are considered to have a direct impact on entrepreneurial attitudes (Pajares \& Urdan, 2006). According to experiential learning theory, attitudes are mainly learnt by the experiences in society and environment where persons face a variety of circumstances during their life or occupation (Politis \& Gabrielsson, 2009).

Entrepreneurial Motivation - Entrepreneurial motivation has been considered as a psychological procedure that takes place with diverse intentions of the individual's different levels of perception and factors accountable for the stimulus (Hussain, Scott \& Hannon, 2008; Solesvik, 2013). Further, it has been recognized that a single motive has the ability to make a person to become an effective entrepreneur and intentions could arise due to a range of internal and external causes (Shane, Locke \& Collins, 2003). Literature has proved that new venture performance is found to be affected by entrepreneurial motivation and organization factors (Baum et al., 2001). Empirical studies have proved that lack of suitable attitudes and resources of students who run enterprises in transitional economies can hinder the progress of the enterprise indicating the vital connection between the entrepreneurial motivation and EL (Solesvik, 2013). It has been recognized that universities are in a position to enhance EL by developing motivation and competence of the graduates to turn out to be leading personalities in the innovative and entrepreneurial process (Rasmussen \& Sorheim, 2006).

Entrepreneurial Traits - Personality traits are typically defined as descriptions of people in terms of relatively stable patterns of behavior, thoughts, and emotions. Traits are personal attributes or behaviours of people which vary among 
individuals and the effects of combined traits can exhibit indirect links with other variables (Baum \& Locke, 2004). It is stated that entrepreneurial perceptions and actions can be understood by observing or learning entrepreneurial traits (Yan, 2010). Accordingly determination is identified as a trait that can result sustained entrepreneurial actions and vigor, by entrepreneurs even under stress, towards achieving the set objectives of learning (Baum \& Locke, 2004). Although entrepreneurial traits have very slight or no explanatory power their effects can be seen through specific, non trait means, such as goals, efficacy, and vision for the learning (Baum \& Locke, 2004). EL can be described as a behavioral and social activity taking place while an individual intermingles with other persons with a view to identify and capture opportunities (Rae, 2003). Results of some research studies which attempted to distinguish between the personality traits among entrepreneurs and a group of non entrepreneurs, gave rise to the idea that entrepreneurship can be learnt. It has been accepted by scholars in EL that the traits are possible to be learnt and would be helpful for a person to run a business project successfully (Baum \& Locke, 2004). While it is noteworthy to acknowledge the fact that entrepreneurial traits can have an impact on learning method chosen by the entrepreneurial learner in the real world, it is clear that considering the numerous traits, individuals have their own preferences on how and why they learn.

\section{DATA AND METHODOLOGY}

This article aims to propose a conceptual framework for empirical investigation of EL giving careful attention to the prevailing literature. Further the narrative style method has been adopted in presenting this article through literature review. Scientists to a great extent accepted the online information to be resourceful and give access to multiple data bases allowing detailed investigation of specific areas within scholarly and subjects' environment (Dahlander \& Gann 2010). Although these databases contain quality publications, very few on the subject of EL could be found within ISI data base. Hence, using the same key words, SCOPUS database was searched for suitable information. Further, Google Scholar was exploded for details relevant to EL. Some of the articles and theses utilized in this review were results obtained from the web of Freefullpdf science base research while information from other different sources was also made use of. The information was scrutinized to check their applicability to the EL and the related dimensions, for inclusion and the articles beyond the scope of this title were eliminated. After carefully reading the relevant articles from different data bases, around 110 were selected to be considered for this article. A thorough search was carried out to be acquainted with the relevant theories and correlations retaining the consistency in the literature (Hayton, George \& Zahra, 2002; Mitchelmore \& Rowley, 2010; Rae, 2001).

Based on the selected dimensions and links recognized by way of the literature review, the proposed conceptual framework was developed relevant to the research problem specified in this article. Hence the following figure 1 represents the essence of reviewed literature enabling an easy access for the conceptual framework as follows.

Figure 1: Conceptual Framework

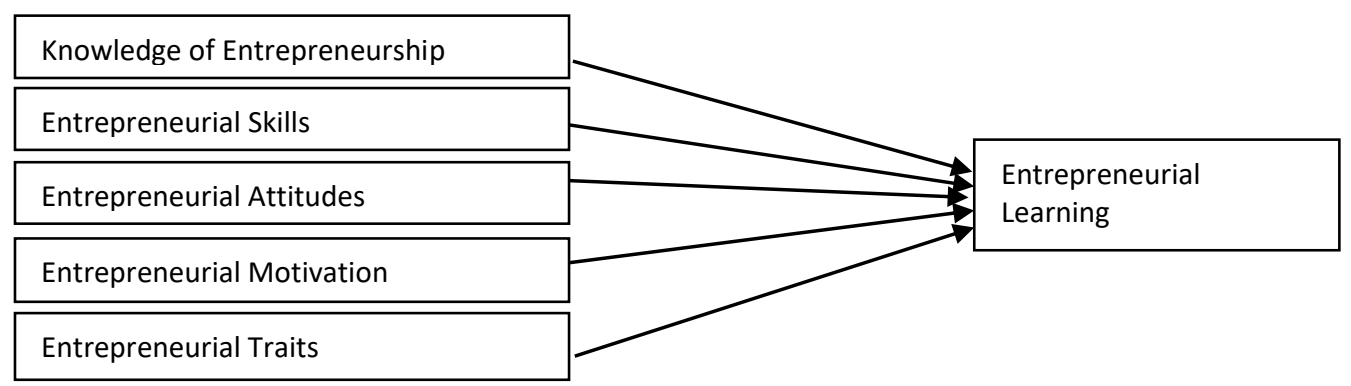

Figure 1 shown above demostrates the relationship between entrepreneurial learning and five selected dimensions. This conceptual framework represents the combined theoriticle views of the literature specially in the context of Sri Lanka.

\section{FINDINGS AND DISCUSSIONS}

The overall aim of this paper was to describe, analyze and synthesize the relevant information in relation to EL and propose a conceptual frame focusing on the connection among selected dimensions and EL construct. This was based on an exhaustive literature review, with a view to investigate its suitability to the up coming Sri Lankan graduate entrepreneurs. The contemporary requirement is to focus on entrepreneurial capacities and mindsets which provide the graduates with creative thinking, effective problem solving, communicating, networking with each other and directing the work which are the relevant tools (Ernest et al., 2015). This has been accepted at the higher education levels, since EL is known as acquiring some specific themes which become useful for working life as an independent entrepreneur. 
Apart from scarcity of quality theories and empirical studies in relation to EL, there is continuing interest in this field to add new knowledge (Royo et al., 2015). The analysis of the selected articles confirmed that the work on EL is fragmented and these lack a common point of origin. The outcomes also revealed that in spite of various arguments, the researchers have missed the chance to work on each other's research while failing to identify the team base leaders in the field of entrepreneurship. It is also observed that the researchers have restricted the studies on EL mainly to their own countries, and the importance of a dialogue between countries in the region need to be highlighted with the idea of sharing knowledge.

The model proposed for EL of graduate entrepreneurs was developed by utilising competency approach coupled with need theory and big five personality model after review of sound literature in this article. Five main dimensions were identified as gaps of research by thorough examination of the relevant literature through which EL of graduate entrepreneurs could be understood. In the present context research conducted in the university system in relation entrepreneurship need to focus on the selected dimensions instead of other factors, as these serve as important contribution to the national economy. A study conducted on influence of entrepreneurial traits and socio- demographic background of undergraduates students on motivation for entrepreneurial career: a case of Sri Lanka (Busige, 2009) reviled that entrepreneurial traits and motivation factors were considered as major areas for the undergraduate studies in the university system of Sri Lanka. One such study forwarded on Entrepreneurial Orientation and Business Performance of Small and Medium Scale Enterprises of Hambantota District in Sri Lanka (Fairoz, 2010) found that knowledge of entrepreneurship is most vital factor for the learning process in the Sri Lankan context. Determinants of entrepreneurial intention: applying western model to the Sri Lankan context (Jagoda, Lin, Carsrud \& Shen, 2013) discussed the relationship between entrepreneurial attitudes and education system in Sri Lanka. Similarity, another research followed on undergraduate intention towards on entrepreneurship: empirical evidences from Sri Lanka (Kumara, 2012) derived the association of self employment focuses on belief and attitudes of the lifelong learning process. In order to fill the gap pertaining to lack of research, this article draws attention to combination of some specific dimensions namely, entrepreneurship knowledge, entrepreneurial skills, entrepreneurial attitudes, entrepreneurial motivation and entrepreneurial traits suggesting a conceptual framework which promotes phenomenal development of this prominent topic. This framework illustrates the possibility of five dimensions having an impact on EL. Overall; it is believed that this article creates a huge potential impact on different stakeholders in the field of entrepreneurship. It is strongly suggested that the model is used as an instrument to form and promote graduate entrepreneurs as excellent business performers. The developed framework is still to be empirically tested and at the same time these dimensions have been clarified and already added to entrepreneurship literature. Hence, this article aims to fill the above identified gaps of EL which is an area that has not been studied earlier. Therefore, this formal framework can be studied empirically and insufficient practical activities do not reduce the value of EL processes (Shane, Locke \& Collins, 2003). Due to these arguments it is observed that shortage of studies on EL in the entrepreneurial process is critical (Baumol, 1968). Consequently, this article will assist to determine whether EL facilitates individuals to change their intensions towards entrepreneurship in a positive way. Therefore, the conceptual framework developed in this article, will lead a new path for future research to be directed to reveal whether these dimensions have a link in relation to EL for the upcoming graduate entrepreneurs in the Sri Lankan context.

\subsection{Implications}

The conceptual framework proposed could be a vital area for studies to be undertaken in this field and the suggested constructs would be empirically tested to confirm the theoretical assumptions illustrated in this article. In order to assess the entrepreneurs' competencies, attention could be given to the measures used in the previous work of this field (Ernest et al, 2015; Garavan \& O'Cinneide, 1994; Gibb, 1994; Sanchez, 2011; Stoof, 2005). As literature suggests, entrepreneurs' competencies are a combination of entrepreneurial knowledge, entrepreneurial skills, entrepreneurial attitudes (Earnest et al., 2015), along with motivation and traits (Deci \& Ryan, 2002) which has a relationship with EL as considered in this article. These main components are discussed with the aim of focusing on the future exploration of new research.

Entrepreneurial knowledge is considered a vital component in the developed framework which has a link with EL and it helps to determine the entrepreneurs learning requirements by focusing on the individuals and venture progress (Earnest, et al., 2015). Furthermore, the knowledge is considered to be enhanced by the entrepreneur's constant way of thinking (Politis, 2005). The literature also highlights on an academic entrepreneurship framework which recommends a sequence of rationally connected conceptual fundamentals to clarify the process of academics providing a variety of knowledge (Brennan \& McGowan, 2006) which proves the priority given to the knowledge factor. It is noteworthy that in the absence of this concept the knowledge gap becomes wider while its presence deem to narrow this knowledge gap and enhances the future research implications.

In relation to the next component of the competency approach, the future researchers are in a position to analyze the entrepreneurial skills following a number of arguments in the literature (Fayolle \& Gailly, 2008; Heinonen \& Poikkijoki, 
2006; Okudan \& Rzasa, 2006; Zhao, Seibert \& Hills, 2005). It is noteworthy to understand in conducting future research, that exact skills are required for different functions in an organizational setting. This becomes clear from the case of graduates where they have to conduct research and development on different perspectives considering the concept of entrepreneurial skill which becomes vital for future implications. The consequences of this article can serve as an opportunity to make use of the practical and theoretical knowledge and skills on real life experiences (Jones \& Jones, 2011). It is noteworthy to understand that participants of EL programs who possess uneven skill levels can lead to unsatisfactory learning by themselves and it is vital to have skills facilitators to avoid departing of participants and create a beneficial EL environment (Steele, 2016). In the absence of the concept of skill in their learning environment the engagement in multipurpose activities of graduates can get discouraged while its presence in adequate quantities will lead to create variety of abilities as well as future research implications.

The third component of competencies is the entrepreneurial attitude and researchers could analyze the behavior and the opinions expressed by many authors in the literature (Jones \& Jones, 2011). It has been highlighted that in some of the studies entrepreneurial attitude was chosen as the main key entrepreneurial competence by all respondents (Ernest et al, 2015) while superior attitudes led to the achievement and preference of an entrepreneurial career. Undoubtedly it is accepted that education can have an influence on students' attitudes leading them to initiate entrepreneurship and their entrepreneurial self efficacy (Dabale, 2014). It is believed that entrepreneurial attitudes and general intentions to become entrepreneurs are activated from attending lively entrepreneurial programs (Dabale, 2014) while the absence of such behavior can influence negatively in future research implications.

The fourth component of this conceptual framework is motivation and many authors have recently analyzed it in detail and empirically tested (Scott et al., 2015). Researchers use this developed scale in order to study the respondents' selection of components and EL in the learning environment path and incidence of shifting within and across various types of situations. It is generally accepted that persons who selected entrepreneurship as their career path come across many different push and pull factors which finally settle on and assist their entrepreneurial process (Matlay \& Storey, 2003 as cited in Dabale, 2014). The added real value to feasibility of business success caused by entrepreneurial training and entrepreneurial attitudes along with intentions to become future entrepreneurs can be activated from exposure to an entrepreneurial program (Dabale, 2014)

The component of individual traits can also be studied as another method in future research to find its link with EL with a view to enhance the awareness of the relationships and the learning procedures (Deakins, O'Neill, \& Mileham, 2000). EL is thought to have an effect and reflect in organizational learning within new and small firms, since an entrepreneur generally dominates as the vital performer of the organization, and create processes which enhance adjustability and the capacity to react to constant change (Johannisson, 2000). Therefore it is anticipated that by improving entrepreneurial traits which can highly enhance individual attempts leading to innovation and success of the new research implications while the absence of these characteristics may result in de-motivation to conduct new research.

By and large, there is an absolute requirement to educate students in many different institutes providing tertiary education enabling them to survive in vibrant societal and economic situations by strengthening them with knowledge, skills, attitudes, motivation and traits leading to running ventures and administering individual businesses (Plaziak \& Rachwal, 2014; Scott et al., 2015; Deakins, O'Neill, \& Mileham, 2000). Enhancing these competences to begin a fresh start-up or running an existing firm is the diverse aims and objectives of Stenholm EL (hytti, \& Heinonen, 2010). Thus, the key role of effective programs is believed to be, to comprehend these various objectives and apply them in the designing of EL studies (Earnest et al., 2015). Overall view of this article is to focus on the implications for future research on EL.

The implications presented in this article may possibly provide a foundation for practical studies for future. The results obtained through the literature survey indicates that learning entrepreneurial competencies and detection serve as the foundation for entrepreneurship, and that EL need to be envisaged as a lasting activity with constantly updated knowledge (Sullivan, 2000). Therefore, the expansion of individuals' awareness in entrepreneurship can be regarded as a leisurely and step by step accumulation process which is spread all the way through their education and quality lifestyles. This indicates that any efforts to encourage entrepreneurship by way of enhancing knowledge can have powerful and straight influence on the expansion of awareness of entrepreneurship. It is clear that any policy implication on educational activities for stimulating EL need to be mainly focused on enhancing entrepreneurial competencies which is a combination of knowledge, skills, attitude, motivation and traits throughout their education and professional lives. In addition, research indicates that increasing competency helps exact business commencement, initial processes prior to the business coming to existence and other actions during their work lives (Ernest et al, 2015). Hence, any policy intending to encourage persons to embark on entrepreneurial activities need to be focused on attempts to make entrepreneurship very striking as a potential career. 


\section{CONCLUSION}

As a whole, it becomes clear that research conducted up to now, education activates of graduates lack a general frame, where queries on the subject of EL still remain unreciprocated. Examining the results of competencies of graduates only in relation to knowledge, skills and attitudes are of little relevance to the field as there are many other components that serve the purpose. Hence the important implication would be the inclusion of other competencies that has an impact on EL as a process, and how these relationships occur throughout the entrepreneurial actions. Therefore the need arises to carry out more detailed and intensified empirical research to study the association of EL and its sub-dimensions, with the intension of incorporating more future research on this field.

It is therefore significant that policy makers within the educational industry focuses a proactive minds to the learning system of graduate entrepreneurs for economic advancement by making an apprise decision making about the entrepreneurial competencies, traits of entrepreneurs and motivation of entrepreneurs recognized. Besides, it also recommended that EL should be a dynamic blend of approaches of dimensions and entrepreneurial action focus of the graduate entrepreneurs in the university system in Sri Lanka.

\section{REFERENCES}

Ahmad, N. H., Ramayah, T., Wilson, C., and Kummerow, L. (2010). Is Entrepreneurial Competency and Business Success Relationship Contingent Upon Business Environment? A Study of Malaysian SMEs, International Journal of Entrepreneurial Behaviour \& Research, 16(3), 182-203.

Ahmed, Z. U., Zgheib, P. W., Carraher, S., and Kowatly, A. K. (2013) Public policy and expatriate entrepreneurs, Journal of Entrepreneurship and Public Policy, 2 (1), pp.42-53, https://doi.org/10.1108/20452101311318666

Aldrich, H. and Zimmer, C. (1986). "Entrepreneurship through social networks", In: D. L. Sexton, and R.W. Similar (Eds), The Art and Science of Entrepreneurship, Ballinger, Cambridge, MA, 3-23.

Amolo, J., \& Migiro, S. O. (2014). Entrepreneurship complexity: Salient features of entrepreneurship, African Journal Business Management 8(19), 832-841. http://doi.org/10.5897/AJBM2014.7442

Bacigalupo, M., Kampylis, P., Punie, Y., Van den Brande, G. (2016).EntreComp: The Entrepreneurship Competence Framework. Luxembourg: Publication Office of the European Union. doi:10.2791/593884

Baldwin-Evans, K. (2006). "Key steps to implementing a successful blended learning strategy", Industrial and Commercial Training, 38(3), 156-63.

Baum, J. and Locke, E. (2004), "The relationship of entrepreneurial traits, skill and motivation to subsequent venture growth", Journal of Applied Psychology, 89(4), 587-598.

Baum, J., Locke, E. and Smith, K. (2001), "A multidimensional model of venture growth", Academy of Management Journal, 44(2), 292-303.

Baumol, W. (1968). Entrepreneurship in economic theory, American Economic Review Papers and Proceedings, 64-71.

Brennan, M.C. and McGowan, P. (2006), Academic entrepreneurship: an exploratory case study, International Journal of Entrepreneurial Behavior \& Research, 12(3) 144-64.

Buckley, P., and Park, B. (2014), realized absorptive capacity, technology acquisition and performance in international collaborative formations: an empirical examination in the Korean context, Asia Pacific Business Review 20(1) 109-135.

Busige, N. (2009) Influence of Personality Traits and Socio-demographic Background of Undergraduate Students on Motivation for Entrepreneurial Career: The Case of Sri Lanka. Ryukuku university institutional repository 49(2) 71-82. Retrieved from http://hdl.handle.net/10519/460

Cope, J. (2011). Entrepreneurial learning from failure: an interpretative phenomenological analysis. Journal of Business Venturing, 26(6), 604-623.

Dabale, W. P., \& Masese, T. (2014). The influence of entrepreneurship education on beliefs, attitudes and intentions: A cross-sectoral study of Africa university graduates. European Journal of Business and Social Sciences, 3(9), 1-13.

Dahlander, L and Gann, D. ( 2010), 'How open is innovation?' Research Policy, 39(6), 699-709.

Deakins, D., O'Neill, E. and Mileham, P. (2000), "Executive learning in entrepreneurial firms and the role of external directors", Education \& Training, 42(4/5), 317-25.

Deci, E.L. and Ryan, R. M. (2002). Self-determination: reflections and future directions, In: E.L. Deci and R.m. Ryan (Eds), Handbook of selfdetermination research, 431-441, Rochester, NY, University of Rochester. 
Dehghani, S., Gharooni, A., and Arabzadeh, A. (2014). Staff Empowerment, Entrepreneurial Behaviors and Organizational Efficiency in Iranian Headquarter Education. Procedia-Social and Behavioral Sciences, 109, 1130-1141. http://dx.doi.org/10.1016/j.sbspro.2013.12.600.

Dermol, V. (2010), Development of Entrepreneurial Competencies. The International Journal of Euro-mediterranean Studies, (IJEMS), 3(1), 27-47.

Entwistle, N. and Ramsden, P. (1983), Understanding Student Learning, Croom Helm, London.

Entwistle, N. J., \& Smith, C. A. (2002). Personal understanding and target understanding: mapping influences on the outcomes of learning. British Journal of Educational Psychology, 72, 321-342

Ernest, K., Matthew, S. K., and Samuel, A. K., (2015). Towards Entrepreneurial Learning Competencies: The Perspective of Built Environment Students. Higher Education Studies; 5(1), 20-30.

Fani, A. (2015). The relationship between knowledge management and organizational learning within middle and senior managers of Iranian public organization. Information and knowledge Management, 5(6), 102-213.

Fayolle, A., and Gailly, B. (2008). From craft to science. Journal of European Industrial Training, 32, 569-593. http://dx.doi.org/10.1108/03090590810899838.

Garavan, T.N., and O'Cinneide, B. (1994) "Entrepreneurship education and training programs: A review and evaluation- part 1" Journal of European Industrial Training. 18(8), 3-12.

Gibb, D. W. (1994). Toward a theory of entrepreneurial careers. Entrepreneurship Theory and Practice,19(2) 7-21.

Harris, J. D., Sapienza, H. J., and Bowie, N. (2009). Ethics and entrepreneurship. Journal of Business Venturing, 24(5), 407-418.

Hayton, J.C., G. George, and S.A. Zahra. (2002). National culture and entrepreneurship: A review of behavioral research. Entrepreneurship Theory and Practice 26(4), 33-52.

Heinonen, J., and Poikkijoki, S. (2006). An entrepreneurial- directed approach to entrepreneurship education: Mission impossible? Journal of Management Development, 25, 80-94.

Houwer, J., Gawronski, B., and Barnes-Holmes, D., (2013). A functional-cognitive framework for attitude research. European Review of Social Psychology, 24(1), 252-287, http://dx.doi.org/10.1080/10463283.2014.892320.

Hussain, J., Scott, J. and Hannon, P. (2008). The new generation: characteristics and motivations of BME graduate entrepreneurs, Education + Training, 50(7), 582-596

Hytti, U., Stenholm, P. and Heinonen, J. (2010). Perceived learning outcomes in entrepreneurship education: the impact of student motivation and team behavior. Education $p$ Training, 52(8/9), 587-606.

Jonassen, D. H. and Grabowski, B. L. (1993). “Handbook of individuals differences: Learning \& instruction” Hillsdale, NJ: Lawrence Earlbaum Assorciates. ISBN: 0-8058-1412-4/0-8058-1413-2.

Jones, A. and Jones, P. (2011). "Making an impact": A profile of a business planning competition in a university, Education $b$ Training 53(8/9), 704-721 DOI 10.1108/00400911111185035.

Kasturiratne, D., (2012), International Enterprise education in Sri Lanka: A blended Approach, Education plus Training 54(4) 306-318

Kiggundu, M.N. (2002). Entrepreneurs and Entrepreneurship in Africa: what is known and what needs to be done, Journal of Development Entrepreneurship, 7(3), 239-258.

Koballa, T. R. (1988). Attitude and related concepts in science education. Science education, 72(2), 115- 126.

Kotey, B. and Meredith, G.G. (1997). Relationship among owner/manager personal values and perceptions, business strategies, and enterprise performance, Journal of Small Business Management, 35(2), 37-64.

Krueger, N.F. (1993), The impact of prior entrepreneurial exposure on perceptions of new venture feasibility and desirability, Entrepreneurship: Theory and Practice 18(1) 5-21.

Kumara, P. A. P. S. (2012) Undergraduates' Intention Towards Entrepreneurship: Empirical Evidence from Sri Lanka. Enterprising Culture,(20)1 105-118. Retrieved from https://doi.org/10.1142/s0218495812500057

Kuratko, D. (2005). The emergence of entrepreneurship education: Development, trends, and challenges. Entrepreneurship Theory and Practice, 29(5), 577-598. http://dx.doi.org/10.1111/etap.2005.29.issue-5.

Lambing, P. A. and Kuehl, C. R. (2007). Entrepreneurship. (4th ed.) Upper Saddle River, NJ: Pearson Prentice Hall.

Lee D.Y. and Tsang, E.W.K. (2001). The Effect of Entrepreneurial Personality, Background and Network Activities on Venture Growth, Journal of Management Studies, 38(4), 583-602.

Lin, X., Carsrud, A., Jagoda, K., and Shen, W. (2013) Determinants of Entrepreneurial Intentions: Applying Western Model to the Sri Lanka Context. Enterprising Culture 21(02) 153. Retrieved from https://doi.org/10.1142/S0218495813500076. 
Man, M. M. K, and Wafa, S.A. (2008). Distinctive Capabilities and the Performance of Small and Medium-Size Enterprises (SMEs) in Malaysia. International Business \& Economics Research Journal, 7(6), 45-59.

Man, T.W.Y., Lau, T. and Chan, K.F. (2002). The competitiveness of small and medium enterprises a conceptualization with focus on entrepreneurial competencies. Journal of Business Venturing. 17(2), 123-142.

Mitchell, A. and Honore, S. (2007), Criteria for successful blended learning, Industrial and Commercial Training, 39(3), 143-9.

Mitchelmore.S. and Rowley. R., (2010) Entrepreneurial competencies: a literature review and development agenda International Journal of Entrepreneurial Behaviour \& Research 16(2) 92-111DOI 10.1108 / 13552551011026995.

Moen, F., and Allgood, E., (2009). Coaching and the Effect on Self-efficacy. Organization Development Journal, 27(4), 69-83.

Murray, H. A. (1938). Explorations in personality. NY: Oxford University Press.

Nicolae, M, Ion, I, \&Nicolae E,(2016) Regional differences in entrepreneurial perceptions and implications for the Romanian competitiveness policy. Management \& Marketing 11 (1), 394-409

Nimalathasan, B. (2008). A Relationship Between Owner-Managers Characteristic and Business Performance, Les ET Scientia International Journal, $X V(1)$. Nugegoda: University of Sri Jayewardenepura.

O’Regan, N., Sims, M. \& Ghobadian, (2005). A. High performance: ownership and decision-making in SMEs. Management Decision, 43(3), 382-396.

Okudan, G. E., and Rzasa, S. E. (2006). A Project-Based Approach to Entrepreneurial Leadership Education. Technovation, 26, 195-210. http://dx.doi.org/10.1016/j.technovation.2004.10.012

Pajares, F., \& Urdan, T. C. (Eds.),(2006), Self-Efficacy Beliefs of Adolescents. IAP.

Perkins, D.N. and Ritchhart. R. (2004). When is good thinking? In D. Y. Dai and R. Sternberg (Eds.) Motivation, emotion and cognition: integrative perspectives on intellectual functioning and development, Mawah, NJ: Erlbaum.

Politis, D. (2005), “The process of entrepreneurial learning: a conceptual framework”, Entrepreneurship Theory and Practice, 29(4) 399-424.

Politis, D. and Gabrielsson, J. (2009). Entrepreneurs' attitudes towards failure: An experiential learning approach. International Journal of Entrepreneurial Behaviour \& Research, 5(4), 364-383.

Poon, M. (2013) Statistically Discriminating Without Discrimination, Centre for the Analysis of Risk and Regulation, London School of Economics. Industry and Innovation, 14(1), 95-119.

Rae, D. (2003), Opportunity centered learning: an innovation in enterprise education, Education $p$ Training, 45(8/9), 542-9.

Rae, D. (2004), Entrepreneurial learning: a practical model from the creative industries, Education $p$ Training, 46(8/9), 492-500.

Rae, D. and Carswell, M. (2001), "Towards a conceptual understanding of entrepreneurial learning", Small Business and Enterprise Development, 8(2). 150-8.

Ranasinghe, S. (2008 October). Factors Contributing to the Success of Women Entrepreneurs in Sri Lanka. 1st research conference organized by National Centre for Advanced Studies.

Rasmussen, E. \& Sorheim, R. (2006). Action-based entrepreneurship education. Technovation. 26(2). 185-194

Royo, M., Sarip, A., and Shaari, R.,(2015), Entrepreneurship Traits and Social Learning Process: An Overview and Research Agenda. Procedia-Social and Behavioral Sciences 171, 745-753

Ruhnau, K. (2006). An analysis of learning outcomes of adult students: learning styles versus teaching styles. A Research Paper. The Graduate School University of Wisconsin Stout.

Sahban, M., Kumar, M. D. and Ramalu, S.S. (2014), "Model confirmation through qualitative research: Social support system towards entrepreneurial desire". Asian Social Science, 10(22), 17-28.

Sanchez, J. C. (2011). University Training for Entrepreneurial Competencies: It's Impact on Intention of Venture Creation. International Entrepreneurship and Management Journal, 7, 239-254. http://dx.doi.org/10.1007/s11365-010-0156-x.

Sarwoko, E., Surachman, Armanu, and Hadiwidjojo, D., (2013). "Entrepreneurial Characteristics and Competency as Determinants of Business Performance in SMEs" IOSR Journal of Business and Management (IOSR-JBM) e-ISSN: 2278-487X. 7(3), (Jan. - Feb. 2013), 31-38 www.iosrjournals.org.

Schmeck, R. (1988). Individual differences and learning strategies. In E. G. Weinstein, \& P. Alexander (Ed.), Learning and Study Strategies 171-191. NY: Academic Press.

Scott, J. M., Thompson, J. L., and Penaluna, A. (2015 November). 'Constructive Misalignment? Learning outcomes and effectiveness in team work / based experiential Entrepreneurship education assessment. In: 38 Annual Institute for Small Business and Entrepreneurship Conference 2015, 11-12, Glasgow. 
Sezen-Gultekin, G. and Gur-Erdogan, D., (2016). The Relationship and Effect between Lifelong Learning Tendencies and Social Entrepreneurship Characteristics of Prospective Teachers. Anthropologist, 24(1), 113-118.

Shane, S., Locke, E. A. and Collins, C. J. (2003). Entrepreneurial Motivation, Human Resource Management Review, 13(2), 257-279.

Sok, P., Snell, L., Lee, W. J. (Thomas), \& Sok, K. M. (2017). Linking entrepreneurial orientation and small service firm performance through marketing resources and marketing capability. Journal of Service Theory and Practice, 27(1), 231-249. https://doi.org/10.1108/JSTP-012016-0001

Solesvik, M. Z. (2013). Entrepreneurial motivation and intentions: investigating the role of education major, Education \& Training, 55(3), 253-271.

Steele, P. K. (2016). "Effective General Entrepreneurial Learning Programs for SME Development" Capstone Collection. Paper 290.

Stoof, A. (2005). Tools for the Identification and Description of Competencies (Thesis Dissertation, Open University of Nederland). Sri Lanka: Aiming for business success (43-44). Colombo.

Thompson, E. R. (2009). Individual Entrepreneurial Intent: Construct Clarification and Development of and Internationally Reliable Metric. Entrepreneurship Theory and Practice, 669-694. http://dx.doi.org/10.1111/j.1540-6520.2009.00321.x.

Toktarova, V. and Mamatov, D. (2015). Implementation of the adaptive learning model based on learning styles Theory \& Practice of Social Development, 8, 231-236.

Wang, C. L. and Chugh, H. (2014), Entrepreneurial learning: past research and future challenges. The International Journal of Management Reviews, 16(1), 24-61.

Wiig, K. (1997), "Knowledge management: an introduction and perspective", Journal of Knowledge Management, 1(1), 6-44.

Yan, J. (2010) "The Impact of Entrepreneurial Personality Traits on Perception of New Venture Opportunity,"New England Journal of Entrepreneurship: 13(2) Article 4. Available at: http://digitalcommons.sacredheart.edu/neje/vol13/iss2/4.

Zhao, H., Seibert S. E., and Hills, G. E. (2005). The Mediating Role of Self-Efficacy in the Development of Entrepreneurial Intentions. Journal of Applied Psychology, 90(6), 1265-1272. http://dx.doi.org/10.1037/0021-9010.90.6.1265.

Zoysa, A. De and Herath, S.K. (2007). The impact of owner/managers' mentality on financial performance of SMEs in Japan: An empirical investigation. 